\title{
Az európai földszabályozás aktuális kihívásai
}

\author{
Az európai földszabályozás aktuális kihívásai, szerk.: Csák Csilla, \\ 2010, Miskolc, Novotni Kiadó
}

Az európai földszabályozás aktuális kihívásai című kötet a Miskolci Egyetem Államés Jogtudományi Karán 2010 novemberében megtartott nemzetközi agrárjogi konferencia előadásainak továbbfejlesztett, szerkesztett változatát foglalja magában. A Novotni Kiadó gondozásában jelent meg 2010 utolsó napjaiban; 21 tanulmány keretében mutatja be a földszabályozással kapcsolatos, legaktuálisabb kérdéseket.

\section{1. Általános bemutatás}

A szerzők a téma jeles szakértői, többnyire magyarországi egyetemi oktatók, akiknek a névsorát külföldi kutatók, valamint kormányzati szakemberek egészítik ki. A kötet elméleti és gyakorlati oldalról egyaránt megközelíti a földügyi szabályozás fontosabb témaköreit, továbbá minden szakjogtudományi nézőpontból megtárgyalja e kérdéseket; így találunk benne agrárjogi, pénzügyi jogi, polgári jogi, európai és nemzetközi jogi megközelítést is.

A szerzők körbejárják a termőföldet érintő valamennyi kérdést, szélesen értelmezve azokat. A kötet szól a versenyképesség jegyében a birtokpolitikai távlatokról, a vadászterületekről és a vadászati jogról, a szerződésen alapuló földhasználati jogokról, a termőföldet érintő jogi szabályozás alkotmányossági normakontrolljáról, a termőföldvédelemröl, a mezőgazdasági üzemröl és más földügyi kérdésekröl is.

A téma aktualitását elsősorban a termőföldtulajdon tagállami polgárok általi megszerzését illető moratórium adja. Európai uniós tagságából fakadó kötelezettsége minden tagállamnak, hogy az áruk, személyek, tőke és a szolgáltatások szabad áramlása elvének megfelelve, valamint a diszkrimináció tilalmát tiszteletben tartva lehetővé tegye a tagállami polgárok számára a földszerzést. E kötelezettség alól azonban Magyarország a Csatlakozási Okmányban engedményt kapott, miszerint e kötelezettségünknek csak a csatlakozásunkat követő 7 év elteltével kell eleget tenni, aminek több oka is van. Egyik okként meg lehet jelölni azt, hogy a magyarországi termőföldviszonyok igen heterogének, a tulajdonviszonyok rendezetlenek, az árak pedig jelentősen elmaradnak a nyugat-európaiakétól.

* Dr. Gyüre Annamária Csilla, doktori ösztöndijas PhD-hallgató, Debreceni Egyetem, Állam- és Jogtudományi Kar, Agrárjogi, Környezetjogi és Munkajogi Tanszék, Debrecen. gyure.annamaria@law.unideb.hu. 
A moratórium idejét az unió - nem sokkal a szóban forgó kötet megjelenése után - három évvel meghosszabbította, továbbra is elfogadva azokat a magyar érveket, melyeket az előzőekben megemlítettem. A parlamentnek e döntés ellenére rövid időn belül meg kell alkotnia az uniós polgárok jogszerü, diszkriminációmentes tulajdonszerzését lehetővé tevő jogszabályokat.

A következőkben a kötet valamennyi tanulmányát bemutatom, noha elég nehéz rendező elvet találni az egyes tanulmányok között. Vannak külföldi, valamint hazai szerzőktől származó írások; vannak, amelyek szorosan a termőfölddel foglalkoznak és vannak, amelyek tágabban közelítik meg e témakört, és olyan írást is találunk, mely - e témakörön kívül - más aktuális és érdekes kérdéssel foglalkozik. A termöfölddel kapcsolatos tanulmányok között találunk olyat, amelyik a moratórium lejártával és a várható (szükséges) lépésekkel foglalkozik arra vonatkozóan, hogyan szabályozzuk ezt a kérdést.

A fentiek alapján megállapíthatjuk, hogy az agrár-, illetve földjogon belül (illetve ahhoz képest) tehát meglehetősen sokszínủ a kötet palettája, s valószínüleg ez indokolja azt az egyszerü „szerkesztési elvet”, amelynek alapján az egyes tanulmányok nem tartalmuk szerint rendezve, hanem a szerzők nevének ábécés sorrendjében követik egymást. Az alábbiakban én is ehhez igazodom, nagyobb teret engedve a föld-, illetve agrárjog témaköréhez szorosabban kapcsolódó tanulmányok ismertetésének.

\section{Az egyes tanulmányokról}

A könyv első írása (Andréka Tamásé) a termőföld birtokpolitikai perspektíváit tekinti át, részletesen bemutatva az előzményeket, értve ezalatt az Európai Unióhoz való csatlakozásunk óta fennálló moratóriumot és körülményeit. A tanulmány hiánypótló, hiszen akkor íródott, amikor még nem lehetett ismerni a kormányzati elképzeléseket arra vonatkozóan, hogyan kívánják a moratórium lejárta után szabályozni a kérdést.

Ezután kitér a meghosszabbítás igényére és aktuális indokaira, aminek lényege annak a veszélye, hogy ha megnyitnák a földpiacot, akkor az spekulatív földvásárlási célpont lenne, ami sértené nemzetgazdasági érdekeinket. A háttérben álló körülmények igen sokszínüek. Magyarországon a földbirtokstruktúra sajátosan alakul: a földbirtoktulajdonok átlagmérete két hektár körül van, ebből adódóan a földhasználati viszonyokat a földbérlet túlsúlya jellemzi, ami egymillió család megélhetését biztosítja. A kárpótlási és részarány-kiadási programok még nem fejeződtek be, és várhatóan még éveknek kell eltelnie, míg ezek rendeződnek. E kárpótlási folyamatok befejezetlensége bizonytalansági tényező, ami nem kedvez a külföldiek tulajdonszerzésének. A magyarországi földterületek átlagára meg sem közelíti az európaiakét, noha az utóbbi években elkezdődött némi felzárkózás. Mindezen okokhoz még hozzávehetjük a gazdasági válság okozta problémákat, s ezek együtt - jelenleg - még nem teszik lehetővé azt, hogy megnyissuk földpiacainkat az uniós polgárok előtt. 
A moratórium meghosszabbításának kezdeményezése - mint említettem - sikerrel járt. Azonban ez a 3 év is vészesen hamar el fog telni. A kötet többi írása arra koncentrál, hogy a termőföldet érintő problémákat felvesse, és ezekre hatékony megoldást kínáljon.

A kötet „A vadászterület kialakításának és a vadászati jog gyakorlásának egyes kérdései" címü írása (Bezdán Anikóé) szintén érdekes, bár kevésbé szorosan kapcsolódik a földszabályozás kérdésköréhez. A szerző a vadászterületek kialakításával, fogalmának meghatározásával, annak határaival, méretével, továbbá rendeltetésével foglalkozik.

A kötet harmadik tanulmánya (szerzője Bobvos Pál) a szerződésen alapuló földhasználati jogokat érinti, ezek közül is külön kiemelve a földhaszonbérletet, és ennek vizsgálja meg az elemeit - fogalmát, a jogviszony jellemzőit, az alanyait, tárgyát, időtartamát, a földhaszonbérleti díjat -, majd elhatárolja a feles bérlettől és a részesmüveléstől. A szerző - statisztikai adatokra támaszkodva - megállapítja, hogy Magyarországon a földbérlet aránya magas, míg több nyugati országban a saját tulajdonon való gazdálkodást részesítik előnyben. Tanulmányának végén megfogalmazza azon kívánalmakat, melyekkel versenyképesebbé tehető a magyar gazdálkodás. Szükségesnek tartja, hogy a szabályozás középpontjába a gazdasági egység helyeződjön, az egyébként elaprózott földterületeket egyesíteni kell, és ennek érdekében megengedett eszköznek találja az ún. üzemszabályozást.

A negyedik szöveg külföldi szerzőtöl származik (Busse, Christian), címe szerint a földhaszonbérleti és az agrárpiaci jog összefüggéseit tárgyalja. Kiindulópontja a német nemzeti földbérleti szabályozás, amit alapvetően a BGB tartalmaz, illetve másik oldalról az uniós agrár-piacszervezés joganyaga. A német közigazgatási bíróságok meghatározó ítéletei alapján a piacszabályozás teremtette vagyoni értékű jogok (mint amilyen a cukorkvóta vagy a tejkvóta) jogi sorsát vizsgálja haszonbérlet, illetve alhaszonbérlet esetén. Rámutat az eltérő nemzeti megoldások következményeire is, amelyekre tekintettel jog-összehasonlító vizsgálatokat sürget (fenntartva az 1997-es agrárjogi kongresszus következtetését, miszerint jogharmonizáció a földbérlet szabályozásában nem lehetséges, de nem is kívánatos).

Csák Csilla írása a termőföldet érintő jogi szabályozás alkotmányossági kontrolljával foglalkozik. Az Alkotmánybíróság a 90-es évek elején már állást foglalt ez ügyben, azonban a kérdések újra felmerülnek. A szerző az EU-jognak való megfelelés problémáját is felveti, amit az Alkotmánybíróság korábban már ugyancsak tárgyalt.

A következő tanulmány (Erdős Éva) az ingatlan-átruházás adójogi kérdéseit elemzi. A személyi jövedelemadóról szóló törvény fogalmai közül az ingatlanét és a vagyoni értékű jogét, továbbá az ingatlan átruházásából származó bevétel, illetve jövedelem meghatározását, az adókedvezmények és mentessége körét mutatja be. Megismerkedhetünk az adójogi változásokkal is, melyek a 2010-es évhez köthetőek. Foglalkozik az illetékjogi vetülettel, az ingyenes átruházás, illetve vagyonszerzési illeték mértékével, az ingyenes vagyonátruházási illetékre vonatkozó előírásokkal.

„Az agrártámogatások és a földvédelem, továbbá a talajvédelem összefüggései” címú írás (Farkas Csamangó Erika) az agrártámogatások rendszerét veszi górcső alá. Ehhez részletesen bemutatja az agrár-környezetvédelmi követelményeket (kör- 
nyezet- és termöföldvédelmi törvényünk szabályait, eszközrendszerét, majd az agrártámogatásokhoz kötődő egyéb előírásokat). Terjedelme miatt ezt a művet inkább nevezhetjük szemlének, mint tanulmánynak.

A „Termőföldvédelem a gyakorlatban” című írás keretében a szerző (Farkasné Molnár Mónika) négy kérdésre keresi a választ. Foglalkoztatja az, hogy miért nincs a termőföldvédelmi törvénynek végrehajtási rendelete; miért nincs útmutató arra vonatkozóan, hogy a földhivatalok hogyan járjanak el egy-egy eljárásban; miért nincs szempontrendszer, mely minden fél kötelezettségeit világosan behatárolná; és végül, hogy valóban a termőföld védelme-e a célja a földvédelemnek.

„A kis hazai földjogi szemle” címet viselő írás (Fodor Lászlótól) egy új földjogi szabályozás indokaként a már említett moratórium lejártán túlmenően az alkotmányozást, az EU egységes támogatási rendszerének a bevezetését, a tulajdonviszonyok rendezetlenségét, a környezeti kihívásokat (a klímaváltozást), valamint a földügyi igazgatás átszervezését is megjelöli. Külön foglalkozik az alkotmányozási folyamat során előkerült, különböző földvédelmi javaslatokkal, majd azt a kérdést vizsgálja, hogy mi vezetett el odáig, hogy a mai napig nincs megfelelő szabályozásunk, melynek lehetővé kellene tennie az uniós polgárok földszerzését, és felsorolja azon problémákat, melyek ez ellen hatnak. Egyik megoldásként azt veti fel a szerző, hogy az állam gyarapíthatja a termőföldvagyonát, mely lehetőség jogi értelemben a mai szabályozás keretei között is adott: az állam az elővásárlási rangsor élén áll. Emellett föleg a nyugat-európai megoldások hazai alkalmazását szorgalmazza.

A következő írás (Hegyes Péteré) már egy speciális területtel foglalkozik, az erdövédelem témakörén belül is középpontba állítva az illegális fakitermelés jogi minősítését. Aktualitását mutatja, hogy napjainkban - a növekvő gázárak miatt - egyre nagyobb erdőterületek kerülnek az illegális fakitermelés áldozatává. A szerző rámutat arra, hogy a korábbi szabályozáshoz (az engedélyeztetési kötelezettséghez) képest a 2009-es erdőtörvénybeli bejelentéshez kötés enyhítést jelent. Az erdőgazdálkodási, valamint az erdővédelmi bírság kapcsán felmerülö jogértelmezési problémák mellett foglalkozik a bejelentés nélküli fakitermeléssel megvalósuló tényállásokkal is, úgymint a szabálysértést jelentő „megélhetési falopással”, valamint a büntetőjog hatálya alá tartozó lopás kérdésével. A szerző álláspontja szerint a fa kivágásával vagy akár csak egy ágának letörésével megvalósul a dolog elleni erőszak, és így már vétségi alakzatnak minősül az akár húszezer forint alatti falopás is, ami már büntetöjogi és nem szabálysértési alakzat.

A következő, ismételten külföldi szerzőtöl (Hollo, Erkki J.) származó írásban a környezeti és élelmiszer-egészségügyi szabályozás egyes kérdéseivel ismerkedhetünk meg. A szerző a vidéki térségben zajló tevékenységek (mint amilyen a mezőgazdaság) szabályozásában szükségesnek tartja az említett (környezeti, illetve élelmezés-egészségügyi) szempontok integrálását, a mezőgazdaság, az élelmiszer-termelés és a vidékfejlesztés közti szoros kapcsolatra tekintettel. Kitér a termékjelölésre, ezen belül a genetikailag módosított szervezetek sajátos helyzetére, illetve az agrárium szereplőire, rámutatva e körben a római, germán, illetve angolszász jogok közti különbségekre is (ezek alapján beszélhetünk pl. ugyanazon szereplő esetében farmerről, tulajdonosról vagy termelöről). Ugyanakkor nem támaszkodik nemzeti jogi alapokra, ezért következtetései a magyar olvasó számára is közvetlenül hasznosíthatók. 
A mezőgazdasági üzemet mint jogi egységet középpontba állító tanulmány keretében a szerző (Kurucz Mihály) az agrárjognak - melyet egy a köz- és magánjog határán álló jogterületnek tekinthetünk - magánjogi megközelítést ad. Ez egy elméletileg nagyon jól megalapozott vizsgálati módszer alkalmazását teszi lehetővé. A szerző számos elővásárlási és elő-haszonbérleti jogot ismertet a termőföldre vonatkozóan, s rámutat az ezek szövevényében rejlő jogalkalmazási nehézségekre. Kitér az ingatlan-nyilvántartás, illetve az ún. tömegvétel és a mezőgazdasági üzem összefüggéseire is.

„Az egységes környezethasználati engedély bevezetése az agrárgazdálkodás szemszögéből" címü írás (szerzője Miklós László) az egyik azok közül, amelyek kevéssé kapcsolódnak a földszabályozás témaköréhez, azonban önmagában is érdekes; az állattartás szemszögéből vizsgálja az egységes környezethasználati engedély szabályozási és jogalkalmazási kérdéseit.

„A termőfölddel kapcsolatos szabályozás pénzügyi jogi aspektusai” címü írásban a szerző (Nagy Zoltán) kiemeli, hogy minden állam számára stratégiai jelentőségü területről van szó, az élelmiszerellátás biztonsága végett. A korábban hatályos - a kilencvenes évek elején megszűnt - földadó rendszerét mutatja be mint történeti előzményt, és ebböl a jogintézményböl bontja ki a jelenleg hatályos rendelkezések értékelését. A hatályos szabályozás lényegi elemei körében adójogi, vagyongazdálkodási, valamint támogatáspolitikai kérdéseket vizsgál. lly módon ennek az írásnak önmagában véve is komplex a tárgya: olvashatunk benne a vagyonátruházás, a bérbeadás, a mezőgazdasági őstermelő adózása, az egységes állami vagyonkezelés, az unió költségvetése stb. időszerű kérdéseiröl is.

„A 'vis maior' szerepe a támogatásokban, különös tekintettel az árvíz- és a belvízhelyzetre" címủ tanulmány (Olajos Istváné) elsőként a támogatási rendszer előzményeivel ismerteti meg az olvasót, illetve bemutatja az egységes támogatási rendszert, melyet a magyar kormány 2009. január 1-jétöl tervezett bevezetni. Ezután ismerteti a kölcsönös megfeleltetés (a kötetben egyébként több helyütt is szereplö) rendszerét, amely egyrészt hozzájárul a fenntartható mezőgazdaság fejlődéséhez, másrészt a közös agrárpolitika olyan irányú kialakításához, ami által az jobban igazodik a társadalmi igényekhez. A rendszer bemutatása során részletesen kitér a megfeleltetési kritériumok 2008-as reformjára. A szerző csak ezek után tér rá a címben megjelölt témára, leírva az eljárás menetét, technikai részleteit, ismertetve az eljáró szerveket is.

„A mező- és gazdasági földingatlan tulajdonának, használatának-hasznosításának és jogátruházásuk szabályozásának lehetőségei az uniós jog tükrében" címủ írás (Prugberger Tamásé) a kötet talán legterjedelmesebb múve. A cím és a tartalom nincs egészen összhangban egymással, hiszen az uniós jog helyett valójában a nyugateurópai országok nemzeti joga jelenti itt a viszonyítás alapját. Az egyes nemzeti szabályozások bemutatását olvasva pedig arra következtethetünk, hogy a nyelvtanilag hibás címből az erdő-(gazdasági) szó hiányzik. E munka is abból indul ki, hogy új szabályozásra van szükség, azonban, mint rámutat, több tényező van, ami megnehezíti a jogalkotó dolgát ezen a téren. A megoldást keresve bőven értekezik a nyugat-európai agrárjogi rendszerekről, az egyszerübb áttekintés érdekében a szakirodalomból ismert, bevett csoportosításokat alkalmazva. 
A következő írás (Raisz Anikótól) sajátos megközelítésből foglalkozik a földtulajdoni és földhasználati kérdésekkel. A szerző emberi jogi nézőpontból vizsgálja a témakört, az Emberi Jogok Európai Bíróságának, valamint az Amerikaközi Bíróságnak a gyakorlatát veszi alapul. Több ponton is összekapcsolódónak tartja a két területet (ti. az emberi jogokat és az agrárjogot); a tulajdonhoz való jog, a tisztességes eljáráshoz való jog, a jogorvoslathoz való jog, valamint az egészséges környezethez való jog révén.

A sorban következő írás angol nyelvü, a földtulajdon és földhasználat egyesült királyságbeli szabályozásával foglalkozik (Rennie, Donald). Mint arról a szerző a konferenciát szervező Magyar Agrárjogi Egyesület folyóiratában, a kétnyelvű Agrárés Környezetjogban korábban már beszámolt, az egyes országrészekben különböző szabályozás érvényesül. Jelen írásában a témakörnek csak egyes elemeit érinti - skót jogászként skót példát véve alapul -, mégpedig a bírói gyakorlat tükrében, utalva az EU közös agrárpolitikájának a nemzeti jogra kifejtett hatására is.

A szellemi tulajdonvédelem és a biodiverzitás kérdésével foglalkozó írással is találkozunk a könyv olvasása során (Szabó Ágnes tollából). E tanulmány - noha témája érdekes és aktuális - ismét azok közé tartozik, amelyek kevéssé kapcsolódnak a kötet és a konferencia célkitűzéseihez.

A Szilágyi János Ede által közölt írás az Európai Unió termőföld-szabályozását vizsgálja, mégpedig az Európai Bíróság (ma: az Európai Unió Bírósága) gyakorlata alapján. Az mindenképpen elmondható, hogy ez az egyik legobjektívebb írás a témáról az eddigi hazai szakirodalomban. Számba veszi az uniós jogszabályokat és a releváns bírói gyakorlatot is. Jól értelmezi a földmoratórium kapcsolatát a belső piaci szabadságjogokkal (ami a Gazdaság és Jog című folyóirat hasábjain 2009/10-ben megjelent, egymással vitázó - és a jelen tanulmány szerzője által is hivatkozott írások nem mindegyikéről mondható el). A szerző véleményét, javaslatait szívesen olvasnánk tanulmánya végén egy összefoglalásban is, kár, hogy az elmaradt.

A kötet utolsó tanulmánya (Tanka Endréé) a magyar birtokpolitikában bekövetkező rendszerváltással foglalkozik. Korábban is megfogalmazott javaslatai szerint változások szükségesek a földtulajdon bejegyzése, a földhasználat, a földvédelem, a földügyi szakigazgatás, az elővásárlási jogok rendszerében, valamint ki kell terjeszteni az állami földtulajdont. Politológiai szempontokat alapul véve ad értékelést a jelenlegi szabályozásról, az agrárgazdaság tényleges folyamataira is tekintettel. Írása ezért (máshol megjelent tanulmányaihoz hasonlóan) jól egészíti ki azokat az elemzéseket, amelyeket a témával foglalkozó, többi jogász szerző készített.

\section{Zárszó}

A fentiekben ismertetett, s az agrárjog, illetve földjog körében legfrissebbnek tekinthető tanulmánykötet egyedülálló abban, hogy több szakterületet, jogágat érintően, átfogó jelleggel kíván hasznos és előremutató tanácsokkal, megoldási javaslatokkal szolgálni a moratórium lejártát követő időszakra, mely kihívásként jelenik meg a jogalkotó számára. A témakör aktualitása aligha vitatható. A kötet - mivel nemzetkö- 
zi konferencia képezte a bázisát, illetve a rendezvény házigazdája részben a CEDR (az Európai Agrárjogi Tanács) magyarországi tagegyesülete volt - a külföldi szakmai közönségnek is szól. Kár, hogy ebben az idegen anyanyelvű olvasót csak a háromnyelvű előszó és a külföldi szerzők angol és német nyelvü írásai segítik, de a tanulmányok mindegyikéhez nem készült idegen nyelvü összefoglaló, ahogyan az angol és német nyelvüeknek sincs magyar nyelvü rezüméje. 